\title{
Dariusz Michalski*
}

Akademia Techniczno-Humanistyczna w Bielsku-Białej

\section{KONCEPCJA MODELU STERUJĄCEGO DLA PRZEDSIĘBIORSTWA Z SEKTORA DÓBR SZYBKO ROTUJĄCYCH}

\begin{abstract}
Streszczenie
Niniejszy artykuł jest wynikiem badań przeprowadzonych przez autora w przedsiębiorstwach sektora dóbr szybko rotujących (FMCG). Stanowi on autorskie rozważania koncepcyjne, mające na celu poprawę wartości generowanej w tego typu przedsiębiorstwach, które nie są częścią koncernów globalnych, mających zazwyczaj wysoko rozwinięte kompetencje i systemy pomiaru dokonań i sterowania kreowaniem wartości dodanej. Stąd zakres podmiotowy artykułu zawężony jest do przedsiębiorstw funkcjonujących poza strukturami globalnych koncernów, zakres przedmiotowy zaś dotyczy właśnie rozwiązań zapewniających w nich skuteczne sterowanie decyzjami menedżerów odpowiedzialnych za wyniki ekonomiczne przedsiębiorstwa. Autor zastosował zarówno metodę obserwacji, jak i analizy oraz krytyki obserwowanych rozwiązań, stosowanych w praktyce gospodarczej. Celem artykułu jest wskazanie rozwiązań zwiększających skuteczność pomiaru dokonań oraz przejrzystości kreowania wartości dodanej w przedsiębiorstwach z sektora FMCG. Autor stosuje styl postulatywny, gdyż istotą artykułu jest zachęcenie do implementacji opracowanego modelu sterującego w przedsiębiorstwach z sektora FMCG w Polsce, aby te w sposób stabilny kreowały swe wyniki ekonomiczne w coraz bardziej dynamicznym otoczeniu.
\end{abstract}

Słowa kluczowe: model sterujący, FMCG, wyniki ekonomiczne, wartość dodana, pomiar dokonań

\footnotetext{
* Adres e-mail: dmichalski@ath.bielsko.pl.
} 
Przedsiębiorstwo z sektora $\mathrm{FMCG}^{1}$, będąc uczestnikiem rynku konkurencyjnego, wykazującego znaczną dynamikę zmienności warunków, w jakich trzeba podejmować decyzje, powinno wykorzystywać wszelkie dostępne metody wspomagające zarządzanie. Zarządzanie to dysponowanie zasobami, które mają doprowadzić do realizacji celów organizacji, przy czym celem podstawowym powinno być osiągnięcie planowanych wartości wyników ekonomicznych, rozumianych jako efekt synergiczny, wypracowany przez przedsiębiorstwo, określany w niniejszym artykule jako wartość dodana. Decyzje podejmowane w tym celu zawsze powinny być przedmiotem pomiaru, bazującego na zdefiniowanych wartościach referencyjnych.

\section{Zdefiniowanie pojęcia modelu sterującego}

Dążąc do zwiększenia elastyczności i transparentności nowych warunków gospodarowania, przedsiębiorstwa z sektora FMCG powinny przeprowadzić zasadnicze zmiany w swej organizacji. Jedną z nich jest przebudowa modelu sterującego w kierunku umożliwiającym przejrzystą alokację elementów rachunku odpowiedzialności do poszczególnych ośrodków odpowiedzialności oraz możliwie najefektywniejsze wykorzystanie zasobów tego przedsiębiorstwa².

Model sterujący opisuje organizację łańcucha tworzenia wartości dodanej w przedsiębiorstwie, podaje referencje dla oceny efektywności menedżerów i determinuje zarządzanie poszczególnymi pozycjami. Określa zarazem nie tylko to, jak decyzje powinny być wydawane, oceniane i raportowane, ale także zasady delegowania prawa do podejmowania decyzji oraz zakres podejmowania ryzyka finansowego (limity) przez poszczególne poziomy odpowiedzialności i komórki organizacyjne. Należy zapewnić za pomocą właściwie zaprojektowanego modelu sterującego powiązanie podejmowania decyzji w przedsiębiorstwie z realizacją jego

\footnotetext{
$1 \quad$ Fast Moving Consumer Goods (FMCG) - do branży FMCG zalicza się przedsiębiorstwa oferujące produkty szybko rotujące, innymi słowy: szybko zbywalne, zaspokające codzienne potrzeby konsumentów, m.in.: artykuły spożywcze, kosmetyki, środki czystości, środki higieny, alkohol, papierosy. Cechą charakterystyczną branży jest wysoka konkurencja nie tylko w zakresie zaspokajania potrzeb konsumentów, ale i szybkości odpowiedzi na zmianę ich gustów i preferencji. Stąd niezwykle istotna jest ciągła identyfikacja produktów, które zapewniają przedsiębiorstwu wymaganą masę marży przy zachowaniu konkurencyjności na rynku.

2 Jako model w niniejszym artykule rozumiany jest wzór, według którego są realizowane w przedsiębiorstwie procesy.
} 
celów. Powinien on zostać wdrożony decyzją strategicznego poziomu zarządzania, konstytuując model alokacji odpowiedzialności do ośrodków odpowiedzialności.

Właściwe zaprojektowanie organizacji przedsiębiorstwa z sektora FMCG wymaga pogrupowania jednorodnych kompetencji w elementach jego struktury, odzwierciedlających poszczególne etapy tworzenia wartości dodanej w organizacji, co pozwala przypisać poszczególne elementy rachunku odpowiedzialności do odpowiednich ośrodków odpowiedzialności i przekazywanie im odpowiedzialności za wyniki podjętych decyzji (mandat decyzyjny) ${ }^{3}$. W ten sposób powstają autonomiczne ośrodki odpowiedzialności, dążące do osiągnięcia celów przedsiębiorstwa. Rozwiązanie to powinno zapewnić:

- jasne przypisanie elementów rachunku odpowiedzialności do określonych ośrodków odpowiedzialności,

- zarządzanie oraz sterowanie rezultatem podejmowania decyzji w racjonalny sposób,

- rozliczenie dokonań menedżerów,

- skuteczne sterowanie działaniami korygującymi realizację planów i zwiększającymi pewność osiągnięcia celów przedsiębiorstwa.

\section{Narzędzia sterowania decyzjami menedżerów wykorzystujące rozwiązania z modelu sterującego}

Podstawowe narzędzia wykorzystywane do sterowania podejmowaniem decyzji przez menedżerów, wspierające realizację celów przedsiębiorstwa, określonych w modelu sterującym, to:

- cele,

- plany,

- budżety,

- raportowanie i śledzenie wyników,

- system motywacyjny.

Zracjonalizowanie podejmowania decyzji poprzez ich odpowiednią synchronizację z celami przedsiębiorstwa sprawia, że menedżer hierarchizuje warianty decy-

\footnotetext{
3 Największym wyzwaniem jest jednak skuteczne wdrożenie przygotowanego rozwiązania do praktycznej działalności przedsiębiorstwa.
} 
zyjne, rozpatrując swoje preferencje oraz oficjalne wymagania odnośnie poziomu zrealizowania wartości dodanej. Wiedza o skuteczności poszczególnych instrumentów sterowania dokonaniami menedżerów przyczynia się do poprawy kreowania wartości dodanej w przedsiębiorstwie z sektora FMCG oraz zwiększenia jego wartości, stąd skuteczne sterowanie decyzjami menedżerów zawsze powinno być powiązane z dążeniem do osiągania celów przedsiębiorstwa.

W świadomym wypracowaniu przyszłych działań przedsiębiorstwa, zorientowanych na osiągnięcie zamierzonych celów i zadań w określonych warunkach, miejscu i czasie oraz z zastosowaniem przewidywalnych środków ich realizacji, kluczowa rola przypada planowaniu. Stanowi ono projekcję przyszłego funkcjonowania każdego przedsiębiorstwa (Duraj, 2000, s. 63). Plan zawiera wartość celu w zakresie wyników ekonomicznych, którą przedsiębiorstwo powinno wypracować pomimo zakłóceń i przypadkowości związanych z jego działalnością. Planowanie zatem to decydowanie o podjęciu określonych działań (wydatkowania zasobów przedsiębiorstwa), mających doprowadzić do zjawisk, które by samoistnie nie zaistniały (Koźmiński, Piotrowski, 2002, s. 179-182). Plan powinien zapewnić sprawne osiągnięcie postawionego celu, stając się także punktem odniesienia dla podejmowania działań korygujących. Jest on skuteczny, jeżeli doprowadzi do osiągnięcia celu przy minimum niepożądanych odchyleń. Należy go traktować jako projekt przyszłej działalności przedsiębiorstwa, który powinien stać się punktem odniesienia dla kreowania oddziaływań sterujących w systemie motywacyjnym.

Budżet odnosi się do spójnego przedstawienia elementów przyszłych wyników (Buk, 2006, s. 142-167). Często jest utożsamiany z opisaniem kosztów, jednakże należy go także postrzegać przez pryzmat przychodów. Budżetowanie w przedsiębiorstwie powinno uwzględniać skutki podejmowania decyzji, przyczyniając się do wspierania podnoszenia jego wartości. Budżet zatem powinien być instrumentem sterowania wyprzedzającego, rezerwującego środki dla skutecznego funkcjonowania przedsiębiorstwa, antycypując także koszty działań korygujących. Proces ten należy rozpatrywać także poprzez pryzmat budżetowania kapitałowego, związanego z prognozowaniem, zatwierdzaniem i kontrolowaniem kapitałów przedsiębiorstwa, niezbędnych do sfinansowania całości jego działalności. 
Rysunek 1. Hierarchia sterowania wynikami ekonomicznymi w warunkach ryzyka finansowego

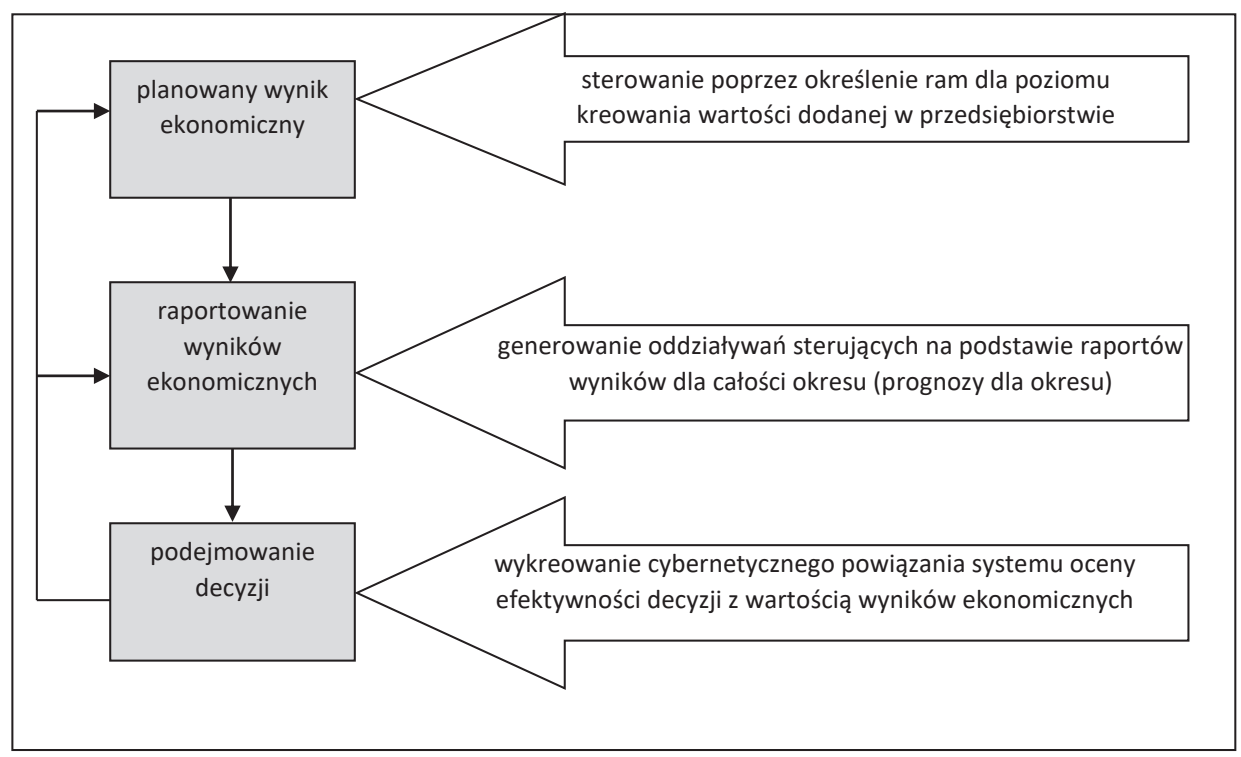

Źródło: opracowanie własne.

Sterowanie przedstawione na rysunku 1 powinno odbywać się w układzie zamkniętym, bazującym na wyprzedzających sprzężeniach zwrotnych. System ten kreuje proces sterowania całokształtem funkcjonowania przedsiębiorstwa, związany z zarząadzaniem kreowaniem wyników ekonomicznych (oczekiwany efekt synergiczny). Połączenie rzeczywistych dążeń decydentów z celami przedsiębiorstwa poprzez ustanowienie wymogu dla poziomu kreacji wartości dodanej staje się narzędziem osiągania celów. W procesie tym plany i budżety wskazują menedżerom metody osiągania celów oraz zasoby będące do ich dyspozycji, a oddziaływania motywacyjne skorelowane $\mathrm{z}$ wartością instrumentu sterowania powinny pobudzać ich do osiągnięcia zaplanowanych celów. Decydent powinien działać jako racjonalizator, co znajduje wyraz w poprawie gospodarowania kapitałem zaangażowanym w działalność przedsiębiorstwa. Wartość wzorcowa instrumentu sterującego - wymóg kreacji wartości dodanej - zostaje określona już na etapie planowania, później jest monitorowana i komunikowana w raportach przygotowywanych przez jednostki organizacyjne realizujące zadania controllingowe. 


\section{Wymóg modyfikacji modelu sterującego przedsiębiorstwa z sektora FMCG}

Rozdzielenie poszczególnych elementów funkcjonowania przedsiębiorstwa z branży FMCG jest ściśle związane ze zmianami w modelu sterującym przedsiębiorstwa, a szczególnie z relacjami pomiędzy jego elementami. Właściwie wdrożony model sterujący umożliwia zamianę każdego elementu wewnętrznego, strukturą spoza organizacji, bez konieczności zmiany zasad rozliczania efektywności.

Funkcjonowanie przedsiębiorstwa z branży FMCG należy podzielić przynajmniej na cztery kluczowe obszary:

- zakupy,

- produkcja,

- logistyka,

- sprzedaż.

Każdy z powyższych obszarów powinien stać się niezależnym ośrodkiem odpowiedzialności, wynagradzanym za efektywność podejmowanych decyzji i generowanie wartości dodanej. Istotne jest zapewnienie prawidłowości pomiaru dokonań po wyizolowaniu wpływu na nie decyzji innych ośrodków odpowiedzialności. Brak prawidłowo ukształtowanego modelu sterującego może prowadzić do nieefektywności wynikającej z obciążania wyników sprzedaży przez rezultaty decyzji podejmowanych w innych komórkach przedsiębiorstwa. W efekcie następuje rozmycie odpowiedzialności i przykładowo rozliczanie jedynie sprzedawców za realizację planowanych przychodów, a nie marż czy EBIT.

Jak wspomniano, istotne jest zapewnienie, że każde z ogniw łańcucha tworzenia wartości w przedsiębiorstwie będzie rozliczane za efektywność własnych decyzji. Jednakże struktura przedstawiona na rysunku 2 nie zapewnia jasnego rozdzielenia odpowiedzialności. Zaopatrzenie nie jest rozliczane za wartość dodaną, generowaną w porównaniu do benchmarku. Produkcja powinna być rozliczana za koszty, na które ma rzeczywisty wpływ - koszty kontrolowane przez produkcję. Jednakże część kosztów stałych bezpośrednich wynika z decyzji sprzedawców i wpływa na wzrost kosztów wydziałowych, co przekłada się na realizację budżetu kosztów produkcji. Logistyka, podobnie jak produkcja, powinna odpowiadać za koszty kontrolowane przez ten obszar, lecz i tu część kosztów może być generowana przez inne obszary, szczególnie sprzedaż, co sprawia, że w logistyce nie ma pełnej kontroli nad kosztami 
powstającymi w magazynach (np. kompletowanie zamówienia składającego się ze znacznej liczby produktów). Podobnie z budżetem transportu: dążenie sprzedawców do wysłania towaru za wszelką cenę, jeżeli ich premia zależy od realizacji planów przychodów w danym okresie, może prowadzić do wzrostu kosztów transportu. Ponadto przedstawione na rysunku 2 rozwiązanie może wskazywać także na negatywny wpływ na poziom celu premiowego logistyki w rezultacie zwiększenia skali wysyłek, co doprowadzi do przekroczenia budżetu transportu. Takie rozwiązanie świadczy o ryzyku braku koordynacji celu logistyki z celami innych ogniw kreowania wartości w przedsiębiorstwie. Sprzedaż może być obciążana nieefektywnością zakupów surowców i materiałów lub wzrostem kosztów w obszarze produkcji i logistyki. Z drugiej strony może odnotowywać korzyści, jeżeli te obszary wypracują nieplanowaną wartość dodaną i wtedy, nawet przy obniżce cen sprzedaży (czyli pogorszeniu efektywności działania sprzedaży), odnotuje lepsze wyniki niż planowano.

Rysunek 2. Nieprawidłowo ukształtowany model sterujący

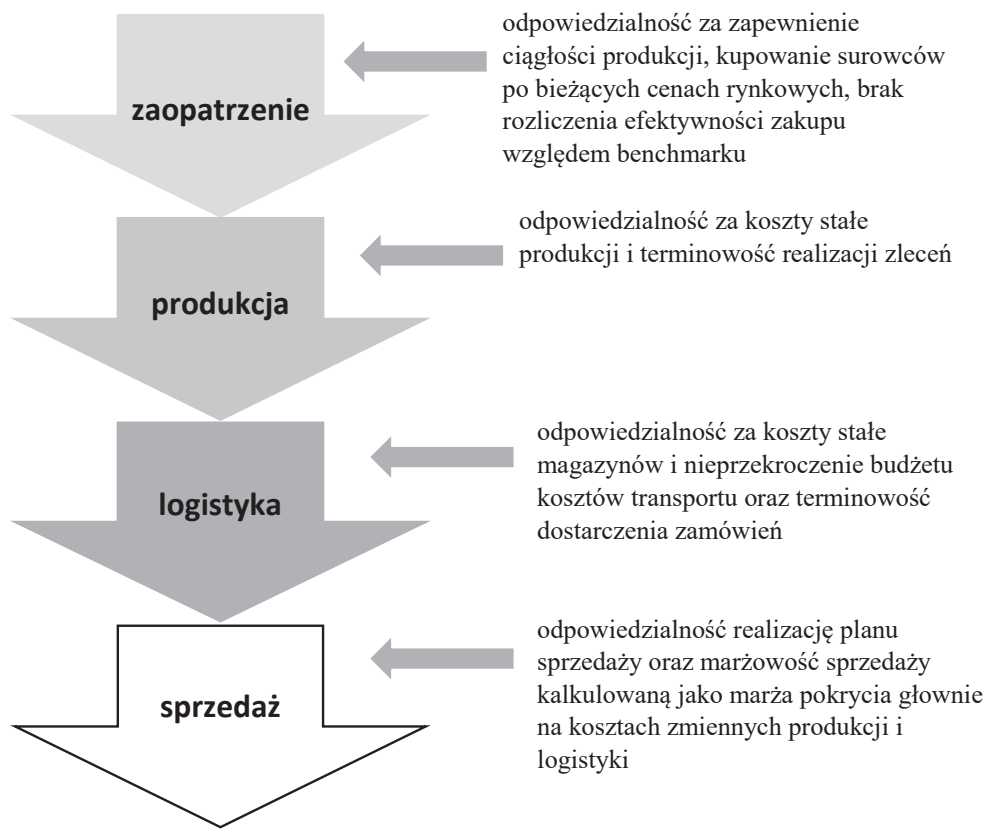

Źródło: opracowanie własne. 
Istotne jest zatem doprowadzenie do wykreowania w przedsiębiorstwie z sektora FMCG skutecznego modelu sterującego, zapewniającego prawidłowy pomiar dokonań menedżerów ośrodków odpowiedzialności oraz koordynację ich celów premiowych - tak aby sterowanie ich decyzjami zapewniało osiągnięcie celów przedsiębiorstwa, co wymaga także precyzyjnej alokacji kosztów kontrolowanych do tych ośrodków odpowiedzialności, które są odpowiedzialne za ich powstanie. Jako koszty kontrolowane należy rozumieć te koszty, na których powstanie ma wpływ menedżer ośrodka odpowiedzialności bez względu na to, czy są to koszty stałe, czy zmienne. Stąd skorygowany model sterujący powinien zostać zaprojektowany w następujący sposób:

- zaopatrzenie - pomiar dokonań powinien zostać uzależniony od dostępności danych:

- zakup surowców, jeżeli tylko są dostępne dane rynkowe, powinien zostać rozliczony za pomocą równania do rynku, obszar zaś powinien wypracować wartość dodaną w stosunku do notowań rynkowych (wynik P/L MtM+4);

$P / L_{R S M T M}=\sum_{i=1}^{n}\left(P_{R i}-P_{W i}\right) \cdot W_{i}(1)$,

gdzie:

$P / L_{R S M T M}$ - wynik wygenerowany na zakupie surowców rozliczany do cen rynkowych;

$i$ - kontrakt;

$P_{R i}$ - cena rynkowa dla i-tego kontraktu;

$P_{W i}$ - cena wykonana dla i-tego kontraktu;

$W_{i}$ - wolumen i-tego kontraktu;

- zakup surowców, jeżeli brak danych rynkowych, to wartość dodana powinna być rozliczona w stosunku do cen zaplanowanych w planie biznesu (budżecie obszaru);

$$
P / L_{R S B}=\sum_{i=1}^{n}\left(P_{B S i}-P_{W i}\right) \cdot W_{i}(2),
$$

$4 \quad \mathrm{MtM}$ (mark-to-market) - równanie do rynku, wycena do rynku 
gdzie:

$P / L_{R S B}$ - wynik wygenerowany na zakupie surowców rozliczany do cen budżetowych;

i - kontrakt;

$P_{B S i}$ - cena budżetowa dla i-tego kontraktu;

$P_{W i}$ - cena wykonana dla i-tego kontraktu;

$W_{i}$ - wolumen i-tego kontraktu;

- zakup materiałów powinien być rozliczany do cen podanych w planie biznesu (budżecie obszaru);

$$
P / L_{R m B}=\sum_{i=1}^{n}\left(P_{B M i}-P_{W i}\right) \cdot W_{i}(3),
$$

gdzie:

$P / L_{R m B}$ - wynik wygenerowany na zakupie materiałów rozliczany do cen budżetowych;

i - kontrakt;

$P_{B M i}$ - cena budżetowa dla i-tego kontraktu;

$P_{W i}$ - cena wykonana dla i-tego kontraktu;

$W i$ - wolumen i-tego kontraktu.

Zaopatrzenie powinno wypracować wartość dodaną (zysk, P/L) w stosunku do wartości referencyjnych (ceny rynkowe, ceny planowane), a cel dla wartości dodanej powinien być podstawą systemu motywacyjnego. Wartość osiąganego wyniku zaopatrzenia należy rozliczyć jak poniżej:

$$
P / L_{Z}=\sum_{i=1}^{n}\left(P_{R i}-P_{W i}\right) \cdot W_{i}+\sum_{i=1}^{n}\left(P_{B S i}-P_{W i}\right) \cdot W_{i}+\sum_{i=1}^{n}\left(P_{B M i}-P_{W i}\right) \cdot W_{i}(4),
$$

gdzie:

$P / L_{z}$ - wynik wygenerowany przez zaopatrzenie.

Jeżeli $P / L_{z}>0$, to zaopatrzenie przyczynia się do wzrostu wartości przedsiębiorstwa. Jednakże część kosztów obszaru zaopatrzenia może wynikać z decyzji sprzedaży (przykładowo wspomniany wymóg żądania skrócenia czasu realizacji zamówienia ze strony sprzedaży), co pociąga za sobą wzrost kosztów zakupu surowców czy 
opakowań. W takiej sytuacji koszty te należy traktować jako koszty kontrolowane przez sprzedaż i po potwierdzeniu realizacji zlecenia przez sprzedaż nadwyżkę kosztów ponad poziom referencyjny należy uwzględnić w wyniku sprzedaży.

- Produkcja - pomiar dokonań powinien dotyczyć wykonania budżetu kosztów stałych kontrolowanych przez ten obszar, co przekłada się na ograniczenie kosztów robocizny czy poprawę efektywności energetycznej, poprawę zarządzania utrzymaniem ruchu maszyn i zarządzania ich remontami. Ponieważ część kosztów stałych to koszty stałe bezpośrednie kontrolowane przez sprzedaż, to należy podzielić odpowiedzialność za nie pomiędzy sprzedaż i produkcję, aby uniknąć niepotrzebnego wzrostu tych kosztów, jeżeli produkcja przestanie nimi zarządzać, a jednocześnie obciążyć wynik sprzedaży wzrostem kosztów stałych, wynikający z decyzji sprzedaży (np. krótkie serie produkcyjne, krótki czas realizacji zamówienia, koszt naprawy maszyn powyżej standardu wynikający z częstych przezbrojeń).

$$
P / L_{P}=K_{K B}-K_{K P W}-50 \% K_{K P W S}(5),
$$

gdzie:

$P / L_{P}-$ wynik wygenerowany przez produkcję;

$K_{K B}$ - koszt zabudżetowany kontrolowany przez produkcję;

$K_{K P W}$ - koszt wykonany kontrolowany przez produkcję;

$K_{K W}-$ koszt wykonany produkcji kontrolowany przez sprzedaż.

- Logistyka - podobnie jak produkcja powinna być rozliczana za koszty, które są kontrolowane w jej obszarze; dotyczy to zaplanowanych kosztów stałych magazynów i kosztów określonych w budżecie transportu. Jednakże także w obszarze logistyki część kosztów jest kontrolowana przez obszar sprzedaży, który może je generować realizując zamówienia wymagającego niestandardowo długiego czasu kompletacji i załadunku. Innym zagadnieniem jest wzrost kosztów transportu ponad standard dla wysyłek, np. w sytuacji dążenia do wysyłki na koniec miesiąca, gdy przewoźnicy zwiększają swoje ceny lub w okresach wysokich cen - przykładowo na koniec kwietnia, co wiąże się z wysokimi kosztami dla przewoźnika, gdyż niektóre państwa 1 maja (a w Polsce też 3 maja) ograniczają 
ruch samochodów ciężarowych, zatem koszty generowane przez decyzje innych obszarów powinny obciążać wyniki tych obszarów, a nie logistyki. Z tego względu wartościami referencyjnymi dla rozliczenia dokonań menedżerów logistyki powinny być następujące wartości:

- planowane koszty magazynów - wartością referencyjną powinien być koszt stały przypadający na paletę przyjętą do magazynu (zaopatrzenie) lub paletę wysłaną z magazynu (sprzedaż) - koszt stały podzielony przez sumę palet przyjętych i wysłanych w zadanym okresie. W ten sposób zapasy nierotujące nie są elementem rozliczenia, co sprawia, że logistyka dba także o poziom zamrożonego kapitału w zapasach, dążąc do redukcji niepożądanych i długo zalegających surowców, opakowań i towarów (tzw. nieroty);

$$
K_{R M}=\frac{K_{B M}}{Q_{P B}}(6),
$$

gdzie:

$K_{R M}$ - jednostkowy, zabudżetowany koszt magazynu przypadający na paletę rotującą na magazynie;

$K_{B M}$ - koszt zabudżetowany magazynów kontrolowany przez logistykę;

$Q_{P B}-$ zabudżetowana liczba palet przyjętych i wydanych z magazynu;

- koszty transportu - wartością referencyjną dla oceny dokonań menedżerów powinien być średni koszt dostarczenia palety przyjęty w budżecie kosztów transportu:

$K_{R T}=\frac{K_{B T}}{Q_{B P}}(7)$,

gdzie:

$K_{R T}$ - jednostkowy, zabudżetowany koszt transportu przypadający na paletę rotującą na magazynie;

$K_{B M}$ - koszt zabudżetowany transportu kontrolowany przez logistykę;

$Q_{P B}-$ zabudżetowana liczba palet przyjętych i wydanych z magazynu.

Wykorzystując formuły (6) i (7), należy określić efektywność funkcjonowania logistyki w następujący sposób (formuła (8)):

$$
P / L_{L}=\left(\frac{K_{B M}}{Q_{P B}}-\frac{K_{W M}+50 \% K_{K M S}}{Q_{P W}}\right) \cdot Q_{W P}+\left(\frac{K_{B T}}{Q_{B P}}-\frac{K_{W T}+50 \% K_{K T S}}{Q_{W P}}\right) \cdot Q_{W P}(8),
$$


gdzie:

$Q_{W P}$ - rzeczywista liczba palet przyjętych i wydanych z magazynu;

$K_{K M S}$ - koszty magazynu kontrolowane przez sprzedaż;

$K_{K T S}-$ koszty transportu kontrolowane przez sprzedaż;

- Sprzedaż - efektywność sprzedaży powinna być określana na podstawie marży wypracowanej w stosunku do cen referencyjnych. Cena referencyjna powinna określać poziom marży pokrycia, zapewniający bezpieczeństwo finansowe funkcjonowania przedsiębiorstwa, ale jednocześnie jej poziom nie może negatywnie wpływać na sprzedaż. Cena referencyjna powinna określać rzeczywistą wartość (definiowaną także jako cena netto), która wpływa do przedsiębiorstwa w wyniku sprzedaży jednostki produktu, stąd cena sprzedaży, która jest porównywana z ceną referencyjną, powinna być obniżona o wszystkie rabaty i instrumenty wsparcia sprzedaży, które stanowią koszty sprzedaży ${ }^{5}$. Ponadto tak określony wynik obszaru sprzedaży powinien zostać pomniejszony o koszty kontrolowane sprzedaży powstałe w zaopatrzeniu, produkcji i logistyce.

$P / L_{S}=\sum_{i=1}^{n}\left(C_{S i}-C_{R i}\right) \cdot W_{i}-\left(K_{K Z}+50 \% K_{K P}+50 \% K_{K L}\right)(9)$,

gdzie:

$P / L_{S}$ - wartość dodana wygenerowana przez sprzedaż;

$C_{S i}$ - cena sprzedaży i-tego kontraktu;

$C_{R i}$-referencyjna cena sprzedaży i-tego kontraktu;

$W_{i}$ - wolumen i-tego kontraktu;

$K_{K Z}$ - koszty kontrolowane przez sprzedaż w obszarze zaopatrzenia;

$K_{K P}$ - koszty kontrolowane przez sprzedaż w obszarze produkcji;

$K_{K L}$ - koszty kontrolowane przez sprzedaż w obszarze logistyki;

$\left(K_{K L}=K_{K M S}+K_{K T S}\right)$.

Rysunek 3 przedstawia schemat rozliczenia dokonań poszczególnych ogniw kreowania wartości dodanej w przedsiębiorstwie z sektora FMCG. Powyższa metoda urealnia w szczególności pomiar dokonań sprzedaży, gdyż wyniki tego obszaru

5 Cena referencyjna powinna podlegać zmianie w ślad za obiektywnymi (rynkowymi) zmianami kosztów w poszczególnych ogniwach tworzenia wartości w przedsiębiorstwie. 
zostają uniezależnione od efektywności zakupów i sprawności operacyjnej produkcji i logistyki. Suma wartości dodanej, wygenerowanej przez każde z przedstawionych na rysunku 3 ogniw kreowania wartości dodanej w przedsiębiorstwie, stanowi globalną wartość dodaną powstałą w przedsiębiorstwie. Przedstawia ona efekt synergiczny, będący ostatecznym wyznacznikiem efektywności pomiaru dokonań zarówno przedsiębiorstwa, jak i jego menedżerów. Formuła kalkulacji globalnej wartości efektu synergicznego wykreowanego w przedsiębiorstwie powinna zatem kształtować się jak poniżej:

$P / L_{P}=P / L_{Z}+P / L_{P}+P / L_{L}+P / L_{S}(10)$

gdzie:

$P / L_{P}-$ wartość dodana wykreowana w przedsiębiorstwie.

Rysunek 3. Pomiar wartości dodanej generowanej w wyniku prawidłowego ukształtowania

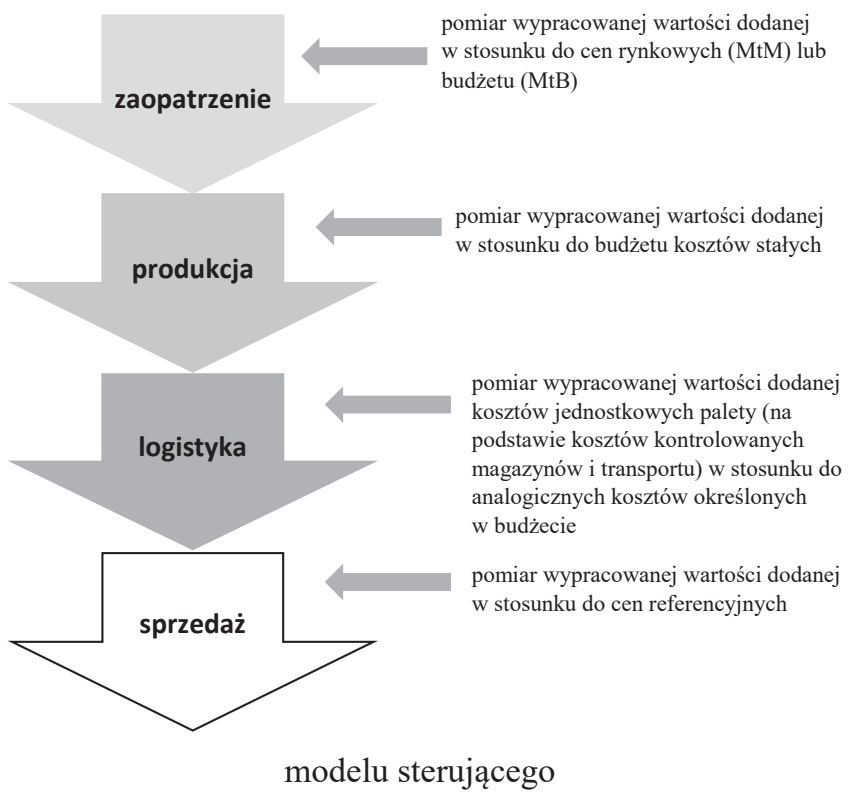

Źródło: opracowanie własne. 
Należy wskazać, że przedstawione rozwiązanie zapewnia elastyczność w zarządzaniu dokonaniami menedżerów poszczególnych ośrodków odpowiedzialności. Charakteryzuje je także brak cen rynku wewnętrznego, co zapewnia prostotę rozwiązania oraz łatwość zastępowalności kompetencji.

$P / L_{S M}=P / L_{P}-P / L_{B}(11)$

gdzie:

$P / L_{S M}$ - wynik będący podstawą dla systemu motywacyjnego;

$P / L_{P}$ - wartość dodana wykreowana w przedsiębiorstwie;

$P / L_{B}$ - wartość dodana określona w planie biznesu przedsiębiorstwa jako wymóg do osiągnięcia.

Wartość $P / L_{P}$ powinna zostać porównana z celem wartości dodanej przyjętym w budżecie i systemie motywacyjnym (formuła 11). Cel globalny dla przedsiębiorstwa powinien zostać przynajmniej skaskadowany do systemu premiowego menedżerów odpowiedzialnych za poszczególne ogniwa tworzenia wartości dodanej, stąd dopiero nadwyżka ponad zabudżetowaną wartość celu dla wartości dodanej stanowi podstawę dla systemu motywacyjnego, wynagradzającego za wysoki poziom dokonań.

\section{Podsumowanie}

Wszystkie decyzje menedżerów podejmowane na różnych szczeblach funkcjonalnych organizacji powinny być zorientowane na generowanie wartości dodanej, dlatego istotne jest prawidłowe jej określenie, odwzorowujące specyfikę funkcjonowania przedsiębiorstwa na konkurencyjnym rynku i zapewniające wygenerowanie skutecznych oddziaływań sterujących. Wartość dodana, konstytuująca wynik ekonomiczny, jest bezpośrednio powiązana z sensem działania każdego przedsiębiorstwa. Jest pochodną przekonania, że dodatkowy efekt synergiczny zostaje osiągnięty w rezultacie właściwego doboru i powiązania w sprawnie funkcjonujące przedsiębiorstwo więzami organizacyjnymi narzędzi i przedmiotów pracy o określonych właściwościach oraz ludzi o określonych kwalifikacjach (opr. własne na podstawie: Krzyżanowski, 1994, s. 167). Wartość dodana przedsiębiorstwa z sektora FMCG powinna być zatem jego celem nadrzędnym. Należy ją traktować jako nadwyżkę 
nad poniesionymi kosztami. Determinuje rzeczywiście tworzony w tym przedsiębiorstwie wynik ekonomiczny, którego wysoki poziom oraz stabilność umożliwia przedsiębiorstwu obniżenie kosztów pozyskania kapitału i to w formie najbardziej odpowiedniej dla jego działalności operacyjnej (zob. też Cwynar, Cwynar, 2012, s. 64-70; Skoczylas, 1998, s. 24-35). Rezultat ten uzyskuje się dzięki prawidłowemu zaprojektowaniu modelu sterującego, zapewniającego pomiar wartości dodanej kreowanej przez każde z ogniw tworzenia wartości dodanej w przedsiębiorstwie z branży FMCG i powiązaniu z nim pomiaru dokonań menedżerów oraz skutecznych instrumentów sterujących podejmowaniem decyzji przez nich w kierunku efektywnego kreowania zysków ekonomicznych.

\title{
Bibliografia
}

Buk, H. (2006). Nowoczesne zarządzanie finansami. Warszawa: C.H. Beck.

Cwynar, A., Cwynar, W. (2002). Zarządzanie wartościa spółki kapitałowej. Warszawa, Fundacja Rozwoju Rachunkowości w Polsce.

Duraj, J. (2000). Podstawy ekonomiki przedsiębiorstwa. Warszawa: Polskie Wydawnictwo Ekonomiczne.

Koźmiński, A.K, Piotrowski, W. (2002). Zarządzanie. Teoria i praktyka. Warszawa: PWN. Krzyżanowski, L. (1994). Podstawy nauk o organizacji i zarządzaniu. Warszawa: Wydawnictwo Naukowe PWN.

Skoczylas, W. (1998). Wartość przedsiębiorstwa w systemie jego oceny. Szczecin: Wydawnictwo Naukowe Uniwersytetu Szczecińskiego.

\section{CONCEPT OF A STEERING MODEL FOR AN ENTERPRISE FROM THE FMCG SECTOR}

\begin{abstract}
The paper results from the research carried out by the author in the enterprises from the FMCG sector. It bases on the the author's conceptual considerations, aimed at improving the value added generated in enterprises from the FMCG sector, acting outside the structures of global corporations that usually have highly developed competences and systems for measuring achievements and controlling the creation of added value. Hence, the scope of the
\end{abstract}


article is limited to the enterprises from the FMCG sector operating outside the structures of global corporations and relates to the solutions that ensure effective control over the decisions of managers responsible for the company's economic profits. The author used both the method of observation and analysis and criticism of the observed solutions used in business practice, having as the objective to indicate solutions that improve the effectiveness of measurement of performance and transparency of the creation of added value in enterprises from the FMCG sector. The author generally uses a postulative style, as the essence of the article is to encourage the implementation of the developed control model in enterprises from the FMCG sector in Poland, supporting the stable way of generation of the economic results in dynamic business environment.

Translated by Dariusz Michalski

Keywords: steering model, FMCG, economic profits, value added, measuring achievements

Kody JEL: M1, M11, M4 